\title{
Non-melanoma Skin Cancer - a Clinicopathological Study of Patients with Basal Cell Carcinoma and Squamous Cell Carcinoma
}

\section{Nemelanómové zhubné nádory kože - klinicko-patologická štúdia pacientov s bazocelulárnym karcinómom a skvamocelulárnym karcinómom}

\author{
Bartoš V. ${ }^{1}$, Kullová M. ${ }^{2}$ \\ ' Department of Pathology, Faculty Hospital with polyclinic Žilina, Slovakia \\ 2 Department of Dermatovenerology, Faculty Hospital with polyclinic Žilina, Slovakia
}

\begin{abstract}
Summary
Background: Non-melanoma skin cancer (NMSC) is the most common malignancy in Caucasians. It mainly includes two major keratinocyte tumors - basal cell carcinoma (BCC) and squamous cell carcinoma ( $\mathrm{SCC}$ ). The objective of the study was to analyze and compare the clinicopathological differences between patients with BCC and SCC of the skin. Material and Methods: A cohort of 541 patients with a total of $719 \mathrm{BCCs}$, and 126 patients with a total of 162 SCCs were retrospectively analyzed. Results: While there was virtually the same proportion of men $(49.91 \%)$ and women $(50.09 \%)$ in BCC patients, SCCs occurred more frequently in men (68.2\%) than in women (31.8\%). The mean age of the individuals with BCC and SCC was 70.8 and 78.2 years, resp. The number of BCCs rises from 50 years of age and this increase showed a linear trend up to 80 years, subsequently followed by decline. SCC lesions occur more rapidly from 70 years of age followed by a sharp increase that exhibited an exponential relationship. $\mathrm{BCC}$ and SCCs occurred predominantly on the head and neck region, comprising a total of $69.8 \%$ and $81.4 \%$ of the cases, resp. However, BCC lesions were seen more often on the face and SCC lesions were diagnosed more frequently on the extra-facial parts of the head. Further, BCCs occurred more frequently on the trunk, and particularly on the back, compared to SCCs. Conclusion: Although BCC and SCC are covered under common term NMSC, they manifest several clinicopathological differences. Despite sharing common etiologic determinants, at least from the onco-epidemiologic perspective, they should be considered separately.
\end{abstract}

\section{Key words}

non-melanoma skin cancer - basal cell carcinoma - squamous cell carcinoma
The authors wish to thank MUDr. Olga Zacharová, MUDr. Dušan Pokorný and MUDr. Jana Doboszová for their educational support and technical assistance.

Autoři děkují MUDr. Olze Zacharové, MUDr. Dušanu Pokornému a MUDr. Janě Doboszové za vzdèlávací a technickou podporu.

The authors declare no conflict of interests regarding the publication of this paper.

Autoři deklarují, že $v$ souvislosti s předmětem studie nemaji žádné komerční zájmy.

The Editorial Board declares that the manuscript met the ICMJE recommendation for biomedical papers.

Redakční rada potvrzuje, že rukopis práce splnil ICMJE kritéria pro publikace zasílané do biomedicínských časopisů.

$$
\risingdotseq^{\circ}
$$

MUDr. PhDr. Vladimír Bartoš, PhD. Faculty Hospital with polyclinic Žilina Vojtecha Spanyola 43 01207 Žilina

Slovakia e-mail: vladim.bartos@gmail.com

Submitted/Obdrženo: 7. 8. 2017 Accepted/Přijato: 25. 9. 2017 


\begin{abstract}
Súhrn
Východiská: Nemelanómové zhubné nádory kože (non-melanoma skin cancer - NMSC) sú najčastejšou malignitou u ludí svetlej pleti. V praxi zahrňujú najmä dva keratinocytové nádory - bazocelulárny karcinóm (basal cell carcinoma - BCC) a skvamocelulárny karcinóm (squamous cell carcinoma - SCC). Ciel'om prezentovanej štúdie bolo analyzovat' a porovnávat' klinicko-patologické rozdiely ochorenia u pacientov s BCC a SCC kože. Materiál a metodika: Hodnotený súbor pozostával z 541 osôb so 719 BCC a 126 osôb so 162 SCC. Výsledky: V skupine pacientov s BCC bolo zastúpenie mužov $(49,91 \%)$ a žien $(50,09 \%)$ prakticky vyrovnané, avšak SCC sa vyskytovali omnoho častejšie u mužov (68,2 \%) než u žien (31,8 \%). Priemerný vek pacientov s BCC bol 70,8 rokov a so SCC 78,2 rokov. Prevalencia BCC začala výraznejšie stúpat’ od 50. roku života, od ktorého mal vzostup lineárny trend až do 80. roku s následným poklesom. SCC sa začal výraznejšie vyskytovat' od 70. roku života, od ktorého prevalencia strmo stúpala a nadobúdala exponenciálny trend. BCC aj SCC boli lokalizované najmä na hlave a krku, ktoré predstavovali 69,8 a 81,4 \% všetkých prípadov. BCC však boli diagnostikované častejšie na tvári a naopak, SCC frekventovanejšie v extrafaciálnych partiách hlavy. Okrem toho sa BCC v porovnaní so SCC vyskytovali podstatne častejšie na trupe, najmä na chrbte. Záver: Hoci sú BCC a SCC zahrnuté pod jednotný termín NMSC, vo viacerých klinicko-patologických znakoch sa odlišujú. Napriek podobným etiologickým faktorom by ich bolo prinajmenej z onkoepidemiologického hladiska vhodné hodnotit' individuálne.
\end{abstract}

Klúčové slová

nemelanómové zhubné nádory kože - bazocelulárny karcinóm - skvamocelulárny karcinóm

\section{Introduction}

Non-melanoma skin cancer (NMSC) is currently the most common malignancy in Caucasians with continuing increase in incidence worldwide [1,2]. Although the term NMSC covers all cutaneous neoplasias that do not originate from melanocytes, it is widely used to refer to two major types of keratinocyte tumors - basal cell carcinoma (BCC) and squamous cell carcinoma (SCC) $[1,2]$. These two forms of cancer account for more than $95 \%$ of all NMSC. BCC comprises about $80 \%$ of the cases, and it is by far the most frequent malignancies diagnosed in people of Caucasian ancestry [1]. In contrast to other neoplasms, BCC generally pursues a favorable clinical course, growing only locally and having minimal (virtually none) metastatic potential. However, some lesions may exhibit an aggressive behavior with a deep tissue infiltration accompanied by repeated recurrences after treatment $[3,4]$. SCC is less frequent, representing approximately $16 \%$ of all NMSC [1]. Its prognosis is slightly worse, as it may sometimes metastasize (0.3-3.7\%) and cause death [2], but this is also a relatively rare finding in a routine clinical practice. In general, despite the fact that overall mortality of BCC and SCC is very low, there may be substantial morbidity due to impossible adequate cure of the lesions and visual disfigurement, as the tumors tend to be located mostly on the head, especially on the face.
Etiological factors that underlie the development of NMSC are multiple and interrelated. They include environmental, phenotypic and genetic determinants [2]. There is persuasive evidence that the key exogeneous (environmental) risk factor for both, BCC and SCC, is ultraviolet radiation (UVR). The others include e.g. arsenic or tar exposure, chronic dermatitis, other chronic dermatoses or HPV infection of the skin, most of which participate especially in SCC pathogenesis [2]. The important phenotypic features associated with increased risk of NMSC include fair or red hair, blue eyes, and Fitzpatrick skin type I and II [2]. Among hereditary conditions, the prototypic disease in which the subjects are susceptible to develop numerous BCCs is Gorlin syndrome [2,5,6]. Another rare genetic disorder, where the persons are sensitive to sunlight and strongly predisposed to various skin malignancies, is xeroderma pigmentosum $[2,5]$. As both carcinomas share similar etiopathogenesis, clinical features and prognosis, they have almost identical treatment strategies and clinical management. On the other hand, certain epidemiologic and clinicopathological aspects differ between them. For example, a development of BCC and SCC is influenced by distinct patterns of UVR exposure [2,7]. Further, while sporadic BCCs usually arise de novo without any precursor lesion, the majority (over $72 \%$ ) of SCCs result from solar keratosis or actinically damaged skin [2]. Reduced immunity (e.g. immunosuppression in organ transplant recipients) is more linked to risk of SCC, especially with an evolution of multiple lesions $[8,9]$. On the contrary, development of multiple sporadic BCCs appears to be much more related to individual genetic predisposition [10].

The objective of the present study was to analyze and compare the clinicopathological differences between patients with BCC and SCC of the skin. We compared our results with relevant literature data in this field.

\section{Material and methods}

The electronic database of Department of Pathology in Faculty Hospital in Žilina was searched using the ICD10 (International Statistical Classification of Diseases and Related Health Problems $-10^{\text {th }}$ revision) codes C44.0-9 and D04.0-9 as the keywords to locate all histopathology reports with a diagnosis of NMSC from January 1, 2010 to June 30, 2017. Among all cases obtained, only diagnoses of BCC, invasive SCC and in situ SCC were accepted. Further, recurrent lesions and subsequent re-excisions after incomplete tumor removal were excluded. Finally, two separate subsets of the individuals with BCC and SCC (both in situ and invasive forms) were gathered and prepared for analysis. The tissue specimens were derived from a variety of clinical sources at our hospital (i.e. departments of surgery, dermatology, 
otorinolaryngology and ophtalmology). Biopsy material was fixed in buffered formalin, embedded in paraffin blocks and stained with hematoxylin and eosin. Medical records of included patients were reviewed to gain basic clinical informations, such as the number of tumors per person, gender, age at the time of diagnosis, topographic locations of lesions and local recurrences arising during the study period. Analysis of histopathologic subtypes and variants of BCC and SCC was not part of the scope of the study. The BCC/SCC ratio was calculated as a ratio between the numbers of the given tumor lesions. Data were collected in a databank, using a software SPSS Statistics. For statistical analysis, chi-square test was employed and $p<0.05$ was considered significant.

\section{Results}

A cohort of consecutive 541 patients (270 males, 271 females) with a total of 719 primary BCCs and consecutive 126 patients (86 males, 40 females) with a total of 162 SCCs (47 in situ, 115 invasive lesions) were included in this study. Among them, 33 subjects ( 25 males, 8 females) had the synchronous or metachronous occurrence of both carcinoma types. The overall BCC/SCC ratio was $4.4: 1$. While there was virtually the same proportion of men (49.91\%) and women $(50.09 \%)$ in BCC patients, SCCs occured much more frequently in men (68.2\%) than women (31.8\%), attaining statistical significance $(p<0.001)$. Patients with BCCs ranged between 23 and 97 years of age (mean 70.8 years with a standard deviation of 12.7, median 71 years). The age group mostly affected by BCC was $71-80$ years. Patients with SCCs ranged between 34 and 95 years (mean 78.2 years with a standard deviation of 9.7, median 80 years). The age group mostly affected by SCC was $81-90$ years. Although both carcinomas were diagnosed mainly in older individuals, there were different patterns in increasing trend of tumor occurrence in relation to age. As for $\mathrm{BCC}$, a number of lesions began to rise apparently from 50 years of age, and this increase showed a linear trend up

Tab. 1. A proportion of BCC and SCC cases in relation to different age categories of patients.

\begin{tabular}{|l|c|c|c|}
\hline Age category (years) & BCC & SCC & BCC/SCC ratio \\
\hline 50 & 52 & 2 & $26: 1$ \\
\hline $51-70$ & 266 & 24 & $11.0: 1$ \\
$71-80$ & 226 & 62 & $3.6: 1$ \\
$81-90$ & 159 & 64 & $2.4: 1$ \\
$\geq 91$ & 16 & 10 & $1.6: 1$ \\
\hline
\end{tabular}

BCC - basal cell carcinoma, SCC - squamous cell carcinoma

The numbers in the table indicate the numbers of tumor lesions.

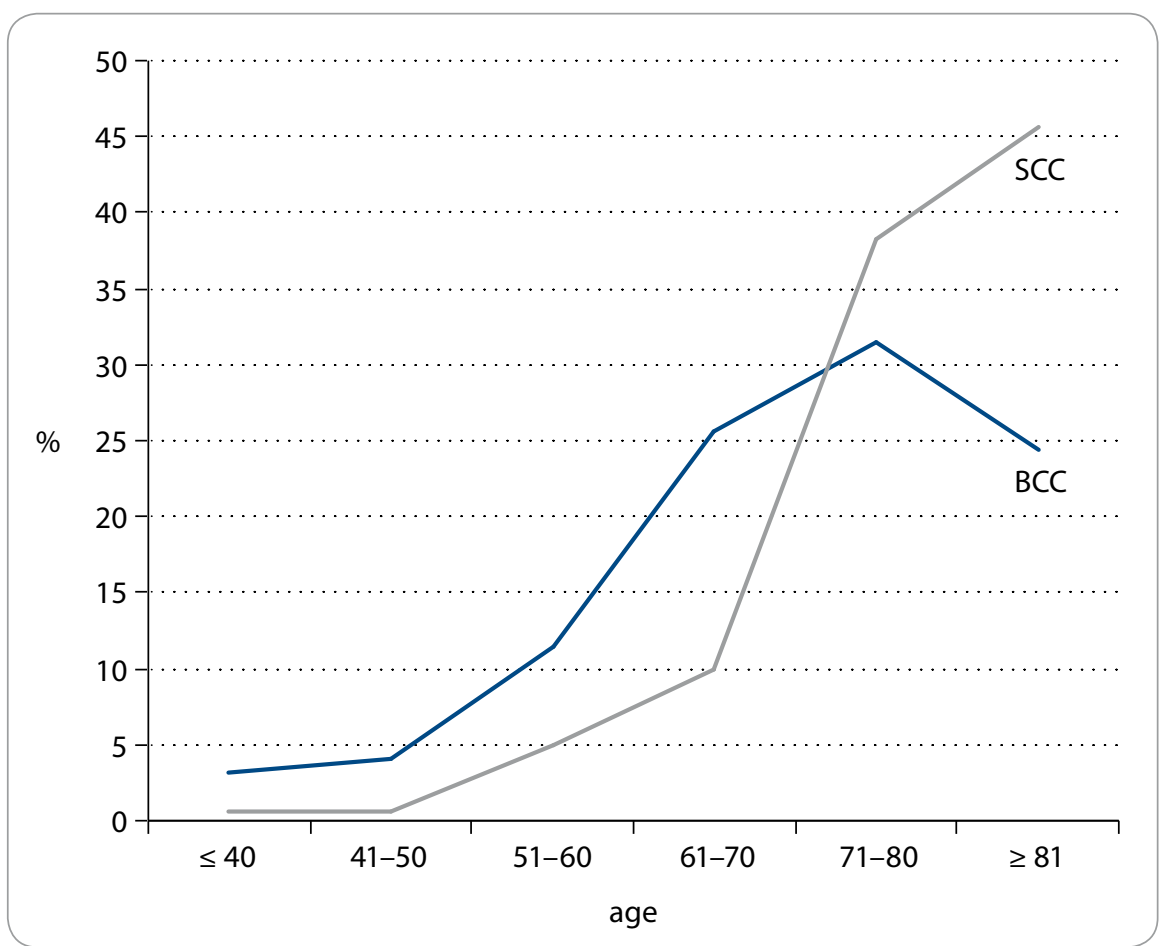

Graph. 1. Different trends in BCC and SCC prevalence in relation to increasing age of population.

BCC - basal cell carcinoma, SCC - squamous cell carcinoma

to 80 , subsequently followed by decline. On the other hand, SCC lesions started to occur more rapidly from 70 years of age followed by a sharp increase that exhibited an exponential relationship (Graph 1). As a result, marked differences in the male to female (M/F) ratio between BCC and SCC subjects in relation to individual age categories were found. While the $M / F$ ratio was $26: 1$ in the youngest population ( $\leq 50$ years), it has been gradually decreasing with rising age and reached a value of $1.6: 1$ in the oldest persons over 90 years (Tab. 1). There were only two SCC patients younger than 50; of these patients, the youngest one (35-year-old female) had a single in situ SCC arising in chronic psoriatic plaque.

As for topographic distribution, BCCs and SCCs occurred predominantly on the head and neck region, comprising $69.8 \%(n=502)$ and $81.4 \%(n=132)$ of the cases, resp. However, BCC lesions were seen more often on the face, compared to SCC $(p=0.01)$ and vice 
Tab. 2. A summary of clinicopathological variables in BCC and SCC patients observed in the present study.

\begin{tabular}{|c|c|c|}
\hline & BCC & SCC \\
\hline Number of patients & 541 & 126 \\
\hline \multicolumn{3}{|l|}{ Sex } \\
\hline - males (M) & $270(49.91 \%)$ & $86(68.2 \%)$ \\
\hline - females (F) & $271(50.09 \%)$ & $40(31.8 \%)$ \\
\hline M/F ratio & $1: 01$ & $2.15: 1$ \\
\hline \multicolumn{3}{|l|}{ Age, years } \\
\hline - mean $( \pm S D)$ & $71.2( \pm 12.7)$ & $78.2( \pm 9.7$ \\
\hline - median & 71 & 80 \\
\hline - range & $23-92$ & $34-95$ \\
\hline Total number of tumors & 719 & 162 \\
\hline Number of tumors per patient & 1.3 (mean) & 1.2 (mean) \\
\hline Patients with $\geq 2$ lesions & $101(18.6 \%)$ & $20(15.8 \%)$ \\
\hline - males & $61(60.4 \%)$ & $15(75 \%)$ \\
\hline - females & 40 (39.6\%) & $5(25 \%)$ \\
\hline \multicolumn{3}{|l|}{ Location of tumors } \\
\hline - face & $317(44.1 \%)$ & $54(33.3 \%)$ \\
\hline - extrafacial parts of the head & $160(22.3 \%)$ & $73(45.1 \%)$ \\
\hline - neck & $25(3.5 \%)$ & $5(3.1 \%)$ \\
\hline - trunk (whole) & $157(21.8 \%)$ & $19(11.7 \%)$ \\
\hline - back only & $118(16.4 \%)$ & $3(1.8 \%)$ \\
\hline - upper extremity & $44(6.1 \%)$ & $4(2.5 \%)$ \\
\hline - lower extremity & $16(2.2 \%)$ & $7(4.3 \%)$ \\
\hline Local recurrence & $30(4.1 \%)$ & $3(1.8 \%)$ \\
\hline
\end{tabular}

BCC - basal cell carcinoma, SCC - squamous cell carcinoma

\section{Discussion}

In the present research, we evaluated and compared available clinicopathological findings in patients' cohorts who suffered from two most common malignant skin neoplasms. This study included 541 patients with BCCs and 126 patients with SCCs. In accordance with earlier Slovak analysis published in 2000 [1], a prevalence of BCC was more than four times higher compared to SCC, resulting in BCC/SCC ratio of $4.4: 1$. Similar values were documented in another report from European countries [11,12]. With regard to the location of tumors, most of the studies published until now have shown that the head and neck region was the most frequently affected body site. It represented $68.4-87 \%$ of all BCCs [1,12-16] and $70.2-77.6 \%$ of all SCCs $[1,12,17]$ analyzed. In the current study, this anatomic part comprised $69.8 \%$ of BCCs and $81.4 \%$ of SCCs diagnosed, corroborating the papers mentioned above. Despite the fact, both skin malignancies occurred predominantly on the body sites, which were permanently exposed to sunlight, BCC lesions developed much more frequently on the trunk, especially on the back, compared to SCCs. These data are similar to those found in the literature $[1,11,12,18]$. It is in agreement with general idea that a chronic (lifetime) exposure to solar UVR plays a major role in SCC development, an intermittent UVR (particularly in childhood and adolescence) seems to be more prejudical etiologic determinant for BCC formation $[2,7]$. It is also in parallel with a finding that increasing age (especially from the seventh decade of life) is accompanied by much higher probability of SCC development, as we illustrated in Tab. 2. As a result, BCC/SCC ratio becomes gradually lower with age, because an increase in risk of tumor development tends to be linear for BCC, but exponential for SCC. In addition, most SCC lesions arise from actinically damaged skin, which is an indicator of cumulative (lifetime) UVR exposure [2]. On the contrary, an association between morphologic markers of cutaneous photodamage and an increased risk of BCC has been proven to be only moderate [19]. 
Regarding gender, we found that SCCs more frequently occurred in men (68.2\%) than women (31.8\%), justifying data from many previous reports $[1,11,12,17,18]$. In BCC, however, the results regarding gender prevalence are much more controversial. While some authors $[1,13,14,16]$ have demonstrated a higher preponderance of men, other investigators $[15,18]$ found higher prevalence of women. In our series, a proportion of men (49.91\%) and women $(50.09 \%)$ affected by BCC was virtually identical. Similar observations have been recently reported by Andrese et al. [12] in North East of Romania. Here it should be mentioned that the traditional incidence pattern, where BCC was more frequently seen in older patients, usually males, seems to be changing. For example, the Dutch [20] and Danish [21] researchers have recently observed marked increase in BCC incidence in younger women younger than 40 . Even data from Great Britain [22] documented that between years 2004 and 2010, the largest average increase in incidence had been observed amongst those aged 30-49 years. During this time, there was a slightly higher increase in BCC incidence in women. The present data suggest that the "typical" BCC patient in northwestern Europe is becoming younger and is more often female. This inversion of prevalence may be associated with new concept of beauty, such as the "culture of tanned skin" with a rising demand for natural and artificial tanning in young women [14]. Further, it could be at least partially explained by the fact that the female population is the target audience for educational campaigns against cancer, making them more aware and careful about their own body $[14,16]$.

A considerable percentage of BCC and SCC subjects had multiple primary tumor lesions, principally the men. The differences between these two carcinoma types were not statistically significant in our study. Multiple (simultaneous or metachronous) development of cutaneous keratinocyte carcinomas is a well-known phenomenon and it is probably the result of both, exogeneous and endogeneous etiologic determinants. According to most literature reports, the proportion of patients with more than one primary BCC represents up to $28 \%$ of the cases $[16,23,24]$. The situation in SCC seems to be similar. In the papers published by Stang et al. [25] and Levine et al. [9], $14 \%$ and $26.1 \%$ of the SCC patients suffered from more than one primary SCC lesion during the 5and 10-years study periods, resp. In our files, the percentage of patients with multiple BCCs (18.6\%) was lower compared to the above-mentioned reports $[16,23,24]$. The main reason may be that we only determined a proportion of the individuals with multiple BCCs among defined patients' cohorts without their precise follow-up. We dealt with this issue in our recent publication in detail [26]. The percentage of persons with multiple primary SCCs (15.8\%) was almost the same as in the study published by Stang et al. [25]. Although it has been previously shown $[8,9]$ that subjects with multiple SCCs were more likely to be immunosuppressed, it was beyond our possibilities to monitor their personal immune status. From a practical point of view, however, once an individual develops NMSC, there is increased risk that a new skin keratinocyte cancer will appear in the next few years. Therefore, all patients with NMSC should be followed-up after treatment. In contrast to many other human malignancies, a secondary prevention of skin cancers (in the form of a total body skin exams) is noninvasive and easily applicable.

Since NMSC only very sporadically leads to metastases, one of the most adverse clinical features of disease is local tumor recurrence. This is a relatively frequent matter in a routine dermatologic practice. The recurrence rate depends on several factors, such as anatomic location and size of lesions, histologic subtypes of tumors, chosen therapeutic modality and resection margin status after total surgical excision. According to literature data, local recurrence rates range between 3.4 and $4.3 \%$ for BCCs $[27,28]$ and between 2 and $3.6 \%$ for SCCs $[27,29,30]$. These values are similar and even some authors [27] did not confirm a statistical significance between $\mathrm{BCC}$ and SCC recurrence rates. In the present study, $4.1 \%$ of all BCC lesions and $1.8 \%$ of all SCC lesions locally recurred during the 7.5-years period, roughly agreeing with the observations from previous studies [27-30]. However, as they represented only microscopically verified cases, a certain number of tumor relapses could have been subsequently treated non-invasively without histopathologic examination.

\section{Conclusion}

Although BCC and SCC are covered under common term NMSC, they manifest several clinicopathological differences. In particular, the most important ones include distinct gender and age predominance and detailed body site distribution. The described variances reinforce the fact that they represent distinct nosologic entities, resulting from different oncogenic pathways. Despite sharing common etiologic determinants, at least from the onco-epidemiologic perspective, they should be considered separately.

\section{References}

1. Plesko I, Severi G, Obsitníková A et al. Tends in the incidence of non-melanoma skin cancer in Slovakia, 1978-1995. Neoplasma 2000; 47(3): 137-142.

2. Samarasinghe V, Madan V. Nonmelanoma skin cancer. J Cutan Aesthet Surg 2012; 5(1): 3-10. doi: 10.4103/09742077.94323.

3. Bartoš V, Adamicová K, Kullová M et al. Basal cell carcinoma of the skin - biological hehaviour of the tumor and a review of the most important molecular predictors of disease progression in pathological practice. Klin Onkol 2011; 24(1): 8-17. doi: 10.14735/amko20 118

4. Bartos V, Adamicova K, Kullova M et al. Comparision of histological types of primary and subsequent relapsing basal cell carcinomas of the skin. Klin Onkol 2012; 25(4): 262-266. doi: 10.14735/amko2012262.

5. Plevová P, Šilhánová E, Foretová L. Vzácné hereditární syndromy s vyšším rizikem vzniku nádorů. Klin Onkol 2006; 19 (Suppl): S68-S75.

6. Plevová P, Krutílková V, Puchmajerová A et al. Gorlinův syndrom. Klin Onkol 2009; 22 (Suppl): S34-S35.

7. Calzavara-Pinton P, Ortel B, Venturini M. Non-melanoma skin cancer, sun exposure and sun protection. G Ital Dermatol Venereol 2015; 150(4): 369-378.

8. Harwood CA, Mesher D, McGregor JM et al. A surveillance model for skin cancer in organ transplant recipients: a 22-year prospective study in an ethnically diverse population. Am J Transplant 2013; 13(1): 119-129. doi: 10.1111/j.1600-6143.2012.04292.x.

9. Levine DE, Karia PS, Schmults CD. Outcomes of patients with multiple cutaneous squamous cell carcinomas: a 10-year single-institution cohort study. JAMA Dermatol 2015; 151(11): 1220-1225. doi: 10.1001/jamadermatol.2015.1702 
10. Ramachandran S, Fryer AA, Smith AG et al. Basal cell carcinomas: association of allelic variants with a high-risk subgroup of patients with the multiple presentation phenotype. Pharmacogenetics 2001; 11(3): 247-254. 11. Stang A, Stegmaier C, Jöckel KH. Nonmelanoma skin cancer in the Federal State of Saarland, Germany 1995-1999. Br J Cancer 2003; 89(7): 1205-1208. doi: 10.1038/sj.bjc.6601294.

12. Andrese E, Solovăstru LG, Taranu T et al. Epidemiological and pathological aspects of skin cancer in North East of Romania. Rev Med Chir Soc Med Nat lasi 2014; 118(2): 457-462.

13. Vantuchová Y, Čuřík R. Hodnocení bazocelulárního karcinomu vzhledem $\mathrm{k}$ histologickému typu, věku, pohlaví a lokalizaci. Čes-slov Derm 2007; 82(3): 140-145.

14. Ferreira FR, da Costa Pevide B, Rodriques RF et al. Differences in age and topografic distribution of the different histological subtypes of basal cell carcinoma, Taubaté (SP), Brazil. An Bras Dermatol 2013; 88(5): 726-730. doi: 10.1590/abd1806-4841.20132145.

15. Souza CF, Thomé EP, Menegotto PF et al. Topography of basal cell carcinoma and their correlations with gender, age and histologic pattern: a retroscpective study of 1042 lesions. An Bras Dermatol 2011; 86(2): 272-277.

16. Mantese OA, Gomides AD, Berbert VC, Rocha A. Basal cell carcinoma - analysis of 300 cases observed in Uberlândia - MG, Brazil. An Bras Dermatol 2006; 81(2): 136-142.
17. Nasser N, Nasser Filho N, Lehmkuhl RL. Squamous cell cancer - 31-year epidemiological study in a city of south Brazil. An Bras Dermatol 2015; 90(1): 21-26. doi: 10.1590/abd1806-4841.20153465.

18. Andrade P, Brites MM, Vieira R et al. Epidemiology of basal cell carcinomas and squamous cell carcinomas in a department of dermatology: a 5 year review. An Bras Dermatol 2012; 87(2): 212-219.

19. Khalesi M, Whiteman DC, Doi SA et al. Cutaneous markers of photo-damage and risk of basal cell carcinoma of the skin: a meta-analysis. Cancer Epidemiol Biomarkers Prev 2013; 22(9):1483-1489. doi: 10.1158/1055-9965.EPI-13-0424. 20. Flohil SC, Seubring I, van Rossum MM et al. Trends in basal cell carcinoma incidence rates: a 37-year Dutch observational study. J Invest Dermatol 2013; 133(4): 913-918. doi: 10.1038/jid.2012.431.

21. Birch-Johansen F, Jensen A, Mortensen L et al. Trend in the incidence of nonmelanoma skin cancer in Denmark 1978-2007: Rapid incidence increase among young Danish women. Int J Cancer 2010; 127(9): 2190-2198. doi: 10.1002/ijc.25411.

22. Musah A, Gibson JE, Leonardi-Bee J et al. Regional variations of basal cell carcinoma incidence in the U.K. using The Health Improvement Network database (2004-10). Br J Dermatol 2013; 169(5): 1093-1099. do 10.1111/bjd.12446.

23. Ramachandran S, Fryer AA, Smith AG et al. Basal cell carcinoma: Tumor clustering is associated with increased accrual in high risk subgroups. Cancer 2000; 89(5): 1012-1018.

24. Verkouteren JA, Smedinga, $\mathrm{H}$, Steyerberg EW et al. Predicting the risk of a second basal cell carcinoma. J Invest Dermatol 2015; 135(11): 2649-2656. doi: 10. 1038/jid.2015.244

25. Stang A, Ziegler S, Büchner U et al. Malignant melanoma and nonmelanoma skin cancers in Northrhine-Westphalia, Germany: a patient- vs. diagnosis-based incidence approach. Int J Dermatol 2007; 46(6): 564-570. doi: 10.1111/j.1365-4632.2006.03056.x.

26. Bartos V, Kullova M. Basal cell carcinoma multiplicity - a retrospective analysis of 899 biopsy-proven patients from a single institute. Klin Onkol 2017; 30(3): 197-201. doi: 10.14735/amko2017197.

27. Chren MM, Torres JS, Stuart SE et al. Recurrence after treatment of nonmelanoma skin cancer: a prospective cohort study. Arch Dermatol 2011; 147(5): 540-546. doi: 10.1001/archdermatol.2011.109.

28. Lee JS, Yi JH, Yun SK et al. Clinicohistopathological study of recurrent basal cell carcinomas after surgical excision. Korean J Dermatol 2010; 48(6): 453-459.

29. Chuang TY, Reizner GT, Elpern DJ et al. Squamous cell carcinoma in Kauai, Hawaii. Int J Dermatol 1995; 34(6): 393-397.

30. Chuang TY, Popescu NA, Su WP et al. Squamous cell carcinoma: a population-based incidence study in Rochester, Minn. Arch Dermatol 1990; 126(2): 185-188. 